\title{
Factors associated with the prevalence of helminths in Mangalarga Marchador horses in southern of Minas Gerais, Brazil ${ }^{1}$
}

\author{
Marina H.F. Rosa ${ }^{2 *}$, Adriana M. Garcia ${ }^{3}$, Débora O. Daher ${ }^{4}$, Imara G. Lima ${ }^{5}$, \\ Marcelle B. Félix ${ }^{6}$, Luiz A. Capellari ${ }^{7}$, Fernando Ferreira ${ }^{8}$ \\ and Christiane M.B.M. Rocha9
}

\begin{abstract}
Rosa M.H.F., Garcia A.M., Daher D.O., Lima I.G., Félix M.B., Capellari L.A., Ferreira F. \& Rocha C.M.B.M. 2018. Factors associated with the prevalence of helminths in Mangalarga Marchador horses in southern of Minas Gerais, Brazil. Pesquisa Veterinária Brasileira 38(6):1097-1104. Departamento de Medicina Veterinária, Universidade Federal de Lavras, Campus Universitário, Cx. Postal 3037, Lavras, MG 37200-000, Brazil. E-mail: mhfrosa@yahoo.com.br

Horses are highly susceptible to parasitism. Helminth infections cause great harm to the animals and to their breeders. This study aimed at evaluating socioeconomic, cultural and management factors associated with the prevalence of gastrointestinal helminths of horses. A total of 40 farmas the Mangalarga Marchador horse breed were visited in southern Minas Gerais, Brazil, where interviews were conducted. Horse feces were collected on the farms and coproparasitological laboratory tests were conducted to quantify the infection and to identify parasites. Data were tabulated in Epidata and analyzed using the SPSS 20.0 software. A great similarity between breeds was observed, specifically in their profiles, as well as in their animal management techniques and in their parasite control habits. The cyathostome was the most prevalent helminth, followed by Oxyuris and large strongyles. The farms which prioritize only equine production are less likely to have animals with massive helminth infection.
\end{abstract}

INDEX TERMS: Prevalence of helminths, Mangalarga Marchador, horses, Minas Gerais, Brazil, small strongyles, cyathostomins, risk factors, epidemiology, parasitoses.

RESUMO.- [Fatores associados com a prevalência de helmintos em cavalos da raça Mangalarga Marchador em propriedades do Sul de Minas Gerais.] Os equinos são animais muito susceptíveis ao parasitismo. As helmintoses causam grandes prejuízos tanto para os animais, quanto para os criadores. Este estudo teve como objetivo avaliar os fatores sócio-econômicos-culturais e de manejo associados à prevalência de helmintos gastrointestinais de equinos.

\footnotetext{
${ }^{1}$ Received June 12, 2017.

Accepted for publication on August 3, 2017.

${ }^{2}$ Departamento de Medicina Veterinária, Universidade Federal de Lavras (UFLA), Campus Universitário, Cx. Postal 3037, Lavras, MG 37200-000, Brazil. Bolsita CAPES. *Corresponding author: mhfrosa@yahoo.com.br

${ }^{3}$ Professor, Departamento de Medicina Veterinária, Universidade Federal de Lavras (UFLA), Campus Universitário, Cx. Postal 3037, Lavras, MG 37200000.E-mail: dricamellogarcia@yahoo.com.br

${ }^{4}$ Departamento de Medicina Vetererinária, Universidade Federal de Lavras (UFLA), Campus Universitário, Cx. Postal 3037, Lavras, MG 37200-000. Bolsista DTI2 CNPq. E-mail: deboradaher@yahoo.com.br

${ }^{5}$ Graduanda em Medicina Veterinária, Iniciação Científica Voluntária, Departamento de Medicina Veterinária, Universidade Federal de Lavras (UFLA), Campus Universitário, Cx. Postal 3037, Lavras, MG 37200-000. E-mail: imara.lima@hotmail.com
}

Foram visitados 40 criatórios de equinos Mangalarga Marchador no Sul de Minas Gerais, nos quais foram realizadas entrevistas. Foram coletadas fezes dos animais nas propriedades e realizados exames laboratoriais coproparasitológicos a fim de quantificar a infecção dos animais e identificar os parasitos. Os dados foram tabulados no Epidata e analisados no software SPSS 20.0. Observou-se uma grande semelhança no perfil dos criadores, assim como na caracterização da propriedade,

\footnotetext{
${ }^{6}$ Graduanda em Medicina Veterinária, Bolsa Iniciação Científica, CNPq, Departamento de Medicina Veterinária, Universidade Federal de Lavras (UFLA), Campus Universitário, Cx. Postal 3037, Lavras, MG 37200-000. E-mail: marcelle.felix@hotmail.com

${ }^{7}$ Graduando em Medicina Veterinária, Bolsa Iniciação Científica, CNPq, Departamento de Medicina Veterinária, Universidade Federal de Lavras (UFLA), Campus Universitário, Cx. Postal 3037, Lavras, MG 37200-000. E-mail: luizcapellari.s@gmail.com

${ }^{8}$ VPS, Universidade de São Paulo (USP), Av. Prof. Dr. Orlando Marques de Paiva 87, Cidade Universitária, São Paulo, SP 05508 270, Brazil. Supervisor Pós-Doutorado CNPq.

${ }^{9}$ Professor, Departamento de Medicina Veterinária, UFLA, Campus Universitário, Cx. Postal 3037, Lavras, MG 37200-000. Bolsista Pós-Doutorado CNPq. E-mail: rochac@dmv.ufla.br
} 
manejo e controle de parasitos. Os ciatostomíneos foram os helmintos mais prevalentes, seguidos pelo Oxyuris e os grandes estrôngilos. As propriedades que priorizam a equinocultura têm menor chance de apresentar animais com infecção maciça.

TERMOS DE INDEXAÇÃO: Prevalência de helmintos, cavalos, Mangalarga Marchador, Minas Gerais, pequenos estrongilhos, ciatostomíneos, fatores de risco, epidemiologia, parasitoses.f

\section{INTRODUCTION}

Horses are animals of great global economic importance and can be used for a wide variety of activities, such as sport, leisure and work. These animals are considered very susceptible to helminths, which affect their health and decrease their performance.

Brazil owns the largest herd of horses in Latin America and is currently the third creator in the world, possessing an average of eight million animals and generating a greater amount than U\$ 7.3 billion a year. Morevover, it is the eighth exporter of horse meat. The largest Brazilian population of horses is located in the Southeast area of the country.

The Mangalarga Marchador horse (MM) is a breed native to Brazil, in the south region of the Minas Gerais state and has gained importance in the world scenario. At a national level, this is a region of great importance in equine production and is considered the birthplace of this breed. MM farms mainly raise animals for trade, breeding, and recreation.

The most common helminths in horses from Minas Gerais are the Strongylinae and Cyathostominae subfamilies and the
Oxyuris and Parascaris genus. The control of helminths in horse farms is still based on the use of chemicals (Molento 2005) and pharmacological bases such as fenbendazole and ivermectin. The resistance of parasites to anti-parasitic products is a concern of veterinary medicine (Molento et al. 2008, Von Samson-Himmelstjerna et al. 2007).

Therefore, it is important to know the reality of horse farms to assess the situation of helminth infections and resistance to anthelmintics to seek new control propositions and to promote animal health. This study aimed at characterizing the prevalence of helminths in MM horse farms in the south of Minas Gerais state, as well as assessing socioeconomic, cultural and management factors associated with the prevalence.

\section{MATERIALS AND METHODS}

A cross-sectional observational ecological study was conducted in 40 randomly selected properties located in the south of Minas Gerais (Fig.1), listed on the Mangalarga Marchador Creators Associations (MM). Data collection was carried out between April 2012 and October 2013.

Interviews were applied to characterize all the properties. Feces samples were collected for identification and for prevalence calculus. The feces were taken directly from the rectum with the aid of lubricated plastic bags, which were identified and taken to the Helminthology Laboratory of the Federal University of Lavras (LH/UFLA) where fecal examinations were performed All animals were free of anti-helminthic treatment for at least two months. Males and females were selected for the study. Animals that were

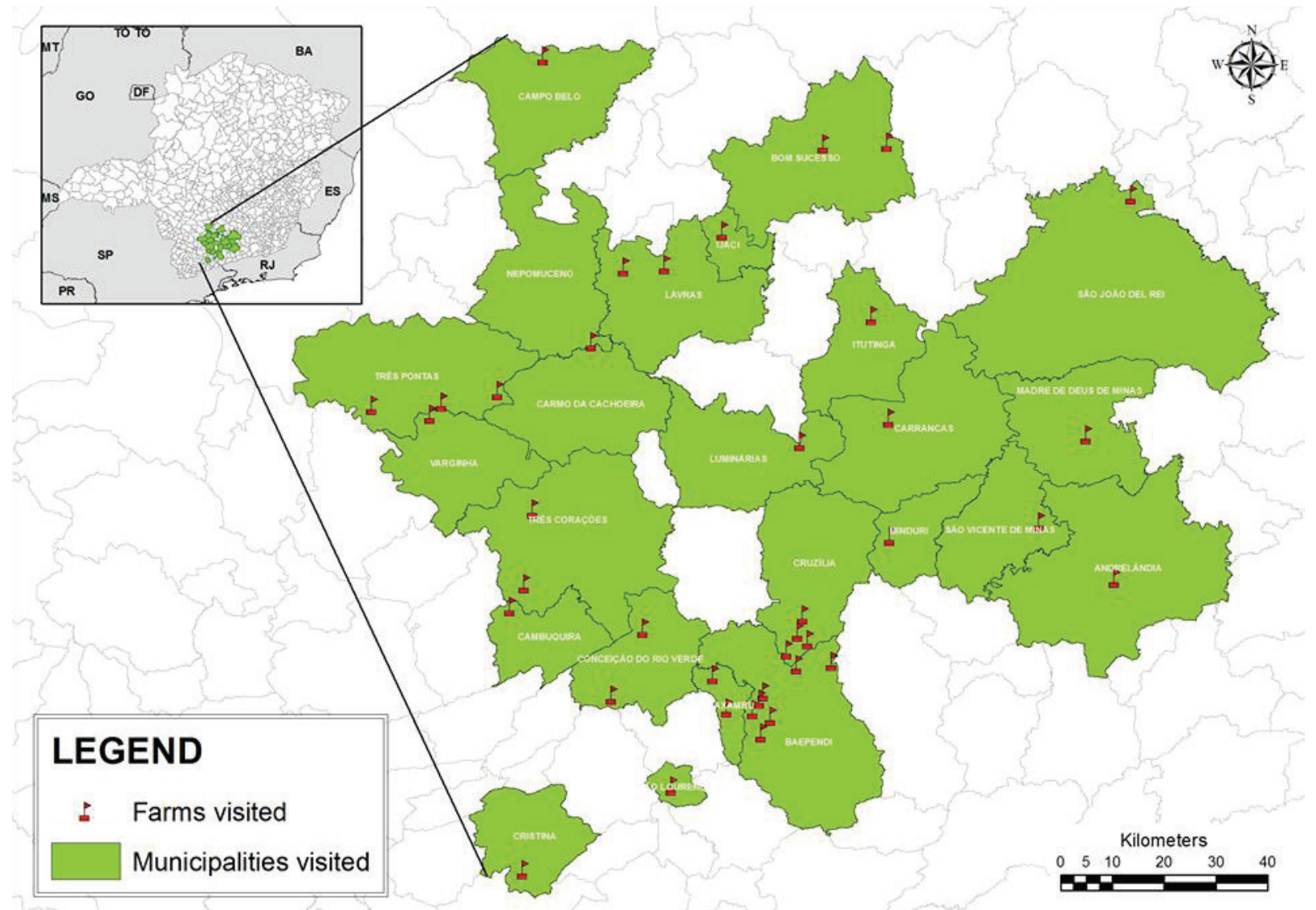

Fig.1. Geographical location of Mangalarga Marchador horse farms in southern Minas Gerais. 
less than six months of age and pregnant females were not added to the study sample.

EPG (egg counts per gram of feces) was performed according to the Gordon \& Whitlock (1939) technique modified by Ueno \& Gonçalves (1998). Coproculture was conducted in positive strongyles samples. Feces were mixed with vermiculite and dried at $27^{\circ} \mathrm{C}$, with controlled humidity for seven days to provide ideal conditions for hatching. After this period, the cultures remained in Baermman apparatus modified for recovery and identification of the larvae.

Larvae were identified using an optical microscope according to morphological parameters following the identification key of Bevilaqua et al. (1993). Furthermore, using a second classification by Kornaś et al. (2009), cyathostome larvae were classified according to the arrangement of the intestinal cells into types A, B, C and D.

The number of strongyle eggs in the EPG (eggs per gram of feces) of each animal was classified according to categories of infection: low infection ( 0 to 450); moderate infection (500 to $1000 \mathrm{epg}$ ); and massive infection (>1000 epg) (Frouco 2011).

The interview was applied to all those responsible for decision making regarding parasite control in the properties, in order to correlate parasite control strategies with laboratory findings. The questions addressed characteristics of the owner and of the property, the management of the animals in general, including animal density, frequency of anthelmintic treatments and drug bases used. Thus, specific questions about the control of parasites in the property, such as anthelmintics used and time intervals usually applied were also asked. The methodology used, from the construction of the interview scripts, as well as the interview procedures, the subsequent analysis of the data and description of the results, was applied according to Rocha et al. (2006, 2011).

Each owner signed a formal consent form to inform the willingness in participating in the project, affirming awareness of the agreement and with all the activities that would be developed in their property and in their animals. The project was approved by the ethics committee of UFLA under Protocol 023/11.

The information was tabulated and codified in EPIDATA. The data was exported and analyzed using the SPSS 20.0 software. A descriptive analysis of all the variables related to the profile of the management of vermifuges in the properties and the results of the laboratory tests was performed. The profile of creators and properties was drawn, highlighting the highest frequencies found, such as: management, management and sanitation according to Rocha et al. $(2006,2011)$.

The prevalence rates are presented by qualitative (low, moderate and massive infestation) and quantitative (prevalence \%, EPG) frequency distributions.

The helminth species found were described and the apparent prevalences were calculated as percentage by species, within properties (\% of affected animals in each property) and among properties (\% of affected properties). Factors associated with the following dependent variables were analyzed: (1) prevalence of infected animals per property (\%), (2) classification of the infection of the animals of the properties, (3) median EPG of animals per property, and (4) median classification of EPG of animals by property. Normality was assessed using the Kolmogorov-Smirnov test in SPSS 20.0. For the quantitative variables that did not follow the normal distribution, the non-parametric tests Mainn-Whittey and Kruskal-Wallis were used. As for the quantitative variables with normal distribution, the T test and ANOVA were applied. Qualitative data and univariate analysis were tested by Pearson's Chi-square to search for statistical associations, with a significance level of 5\% $(\mathrm{p}<0.05)$. The odds ratio was used to measure the magnitude and direction of the association, with a $95 \%$ confidence interval.

\section{RESULTS AND DISCUSSION}

The results of the interviews on characterization of properties, creators, animal handling, control of helminths and biosecurity are described in Table 1 to 5 . The results are in order of

Table 1. Characteristics of breeders and Mangalarga Marchador horse properties in southern Minas Gerais, 2012-2013

\begin{tabular}{|c|c|c|c|c|c|c|c|}
\hline \multirow{2}{*}{ Information } & \multicolumn{6}{|c|}{ Responses in order of frequency } & \multirow{2}{*}{$\mathrm{N}$} \\
\hline & 1st place & $\%$ & 2nd place & $\%$ & 3rd place & $\%$ & \\
\hline Equine as income source & Secondary & 72.5 & Principal & 22.5 & Unique & 5.0 & 40 \\
\hline Main activity in the property* & Equine & 55.0 & Cattle & 25.0 & Agriculture & 12.5 & 40 \\
\hline Time in equine activities & $>30$ years & 43.6 & 10 to 30 years & 35.9 & Up to 10 years & 20.5 & 40 \\
\hline Scholarity of the interviewed & $3^{\circ}$ degree & 72.5 & $2^{\circ}$ degree & 15.0 & $1^{\circ}$ degree & 12.5 & 40 \\
\hline Purpose of creation** & Market & 75.0 & Reproduction & 67.5 & Creation & 59.0 & 40 \\
\hline Labor** & Wage & 100 & Temporary & 77.5 & Both/family & 27.5 & 40 \\
\hline Pasture** & Brachiaria & 72.5 & Tifton & 47.5 & Mombasa & 37.0 & 40 \\
\hline Batch division & Yes & 100 & No & 0 & - & - & 40 \\
\hline Animal location & Bay/picket & 79.5 & Picket only & 15.4 & Bay only & 5.1 & 40 \\
\hline Stalls beds* & Sawdust & 52.8 & Floor & 13.9 & Rest of grass & 11.1 & 40 \\
\hline Time of reproduction* & $\mathrm{MN} / \mathrm{AI} / \mathrm{ET}$ & 57.5 & $\mathrm{MN}$ & 22.5 & $\mathrm{MN}+\mathrm{AI}$ & 17.5 & 40 \\
\hline Cattle presence & Yes & 90.0 & No & 10.0 & - & - & 40 \\
\hline Vaccines** & Rabies & 94.9 & Influenza & 43.6 & Strangles & 20.0 & 40 \\
\hline Participation in events & Yes & 77.5 & No & 22.5 & - & - & 40 \\
\hline Vet & Yes & 87.5 & No & 12.5 & - & - & 40 \\
\hline Visit frequency & Frequent & 50.0 & When necessary & 27.8 & Time of reproduction & 22.2 & 40 \\
\hline Livestock control** & Reproduction & 77.5 & Worming/vaccination & 65.0 & Number of animals & 62.5 & 40 \\
\hline Plans for the future & Improve & 67.5 & Maintain & 17.5 & Increase & 2.5 & 40 \\
\hline
\end{tabular}

* Some categories do not reach $100 \%$ due to the presence of other options that were not tabulated, ** Some categories exceed $100 \%$ because some questions had more than one answer; $\mathrm{MN}=$ Monta natural, $\mathrm{AI}=$ Artificial insemination, $\mathrm{ET}=\mathrm{Embryo}$ transfer. 
Table 2. Quantitative descriptive parameters of Mangalarga Marchador equines properties in southern Minas Gerais, 2012-2013

\begin{tabular}{|c|c|c|c|c|c|c|}
\hline Characteristics & $\mathrm{N}^{*}$ & Minimum & Q1 & Median & Q3 & Maximum \\
\hline Time in equine activities (years)* & 39 & 2 & 14 & 30 & 42 & 70 \\
\hline Employees number* & 39 & 1 & 2 & 4 & 6 & 40 \\
\hline Property total area (ha)* & 37 & 6 & 46.5 & 116 & 269 & 1500 \\
\hline Batches & 40 & 1 & 4 & 5 & 8 & 20 \\
\hline
\end{tabular}

* Categories that $\mathrm{N}$ is less than 40 show losses due to the lack of responses or inconsistencies when answering the questionnaire.

Table 3. Characterization of the management in Mangalarga Marchador horses properties in southern Minas Gerais, 2012-2013

\begin{tabular}{|c|c|c|c|c|c|c|c|}
\hline \multirow{2}{*}{ Information } & \multicolumn{6}{|c|}{ Responses in order of frequency } & \multirow{2}{*}{$\mathrm{N}$} \\
\hline & 1 st place & $\%$ & 2nd place & $\%$ & 3rd place & $\%$ & \\
\hline Feeding* & $\mathrm{MS} / \mathrm{Ca} / \mathrm{Fo}$ & 37.5 & $\mathrm{MS} / \mathrm{Ca} / \mathrm{Fo} / \mathrm{Ha}$ & 32.5 & $\mathrm{MS} / \mathrm{Fo} / \mathrm{Ha}$ & 17.5 & 40 \\
\hline Pasture cleaning & Yes & 87.5 & No & 12.5 & & & 40 \\
\hline Cleaning method & Roça & 97.1 & Arranca & 2.9 & & & 40 \\
\hline Cleaning frequency* & $1 \mathrm{x}$ year & 72.7 & $2 \mathrm{x}$ year & 18.2 & $3 x$ year & 3.0 & 40 \\
\hline Feces cleaning in stalls* & Yes & 92.5 & No & 5.0 & & & 40 \\
\hline Feces cleaning in pickets & No & 87.5 & Yes & 12.5 & & & 40 \\
\hline Feces destination & Capineira & 55.0 & Fertilization & 45.0 & & & 40 \\
\hline Use dunghill & Yes & 57.5 & No & 42.5 & & & 40 \\
\hline Pasture rotation & Yes & 65.0 & No & 35.0 & & & 40 \\
\hline Pasture consortium & Yes & 65.0 & No & 35.0 & & & 40 \\
\hline Exchange stall beds & Yes & 75.0 & No & 22.5 & & 17.5 & 40 \\
\hline
\end{tabular}

MS = mineral salt, Fo = food, $\mathrm{Ha}=$ hay; ${ }^{*}$ Some categories do not reach $100 \%$ due to the presence of other options that were not tabulated.

Table 4. Characterization of the control of helminths in horses in properties in southern Minas Gerais, 2012-2013

\begin{tabular}{|c|c|c|c|c|c|c|c|}
\hline \multirow{2}{*}{ Information } & \multicolumn{6}{|c|}{ Responses in order of frequency } & \multirow{2}{*}{$\mathrm{N}$} \\
\hline & 1st place & $\%$ & 2nd place & $\%$ & 3rd place & $\%$ & \\
\hline Time of occurrence** & Rainy season & 74.3 & Dry & 20.0 & Not know & 12.5 & 40 \\
\hline Feces examination & No & 82.5 & Yes & 17.5 & & & 40 \\
\hline Worming frequency* & $6 / 6$ months & 31.6 & $2 / 2$ months & 26.3 & $3 / 3$ months & 10.5 & 40 \\
\hline All animals vaccinated & Yes & 97.5 & No & 2.5 & & & 40 \\
\hline Used dose* & Follow the lable & 52.5 & + concentrated & 40.0 & - concentrated & 2.5 & 40 \\
\hline Dose* & Right & 52.5 & Wrong & 42.5 & & & 40 \\
\hline Weighting method* & Estimate average weight & 47.5 & One dose for adults and half for foals & 30.0 & Tape weighing & 20.0 & 40 \\
\hline Choice criteria* & Vet & 37.5 & Price & 17.5 & Farmer & 15.0 & 40 \\
\hline Most used dewormer* & Ivermectin & 40.0 & Ivermectin based & 20.0 & Ivermectin + pyrantel & 12.5 & 40 \\
\hline
\end{tabular}

* Some categories do not reach $100 \%$ due to the presence of other options that were not tabulated, ${ }^{* *}$ Some categories exceed $100 \%$ because some questions had more than one answer.

Table 5. Characteristics of biosecurity held in Mangalarga Marchador horse properties Mangalarga Marchador in southern Minas Gerais, 2012-2013

\begin{tabular}{|c|c|c|c|c|c|c|c|}
\hline \multirow{2}{*}{ Information } & \multicolumn{6}{|c|}{ Responses in order of frequency } & \multirow{2}{*}{$\mathrm{N}$} \\
\hline & 1st place & $\%$ & 2nd place & $\%$ & 3rd place & $\%$ & \\
\hline Animal purchase & Yes & 65.0 & No & 35.0 & & & 40 \\
\hline Purchase frequency & >1x year & 57.7 & 1 x year & 23.1 & Rarely & 19.2 & 40 \\
\hline Know the origin & Always & 80.8 & Sometimes & 11.5 & Never & 7.7 & 40 \\
\hline Way of purchase & Vary & 46.2 & Informal & 42.3 & Auction & 11.5 & 40 \\
\hline New animal & Direct & 53.8 & Quarantine & 38.5 & Acaricide & 15.4 & 40 \\
\hline
\end{tabular}


frequency. There is a great similarity in the adopted management and in the form of control of helminths among the evaluated properties. This can be due to the fact that the farmers are all part of the same Mangalarga Marchador association, which appears to standardize the profile of owners and farms.

The profile of the creators is very similar (Table 1). It is observed that $72.5 \%$ of farmers have equine activities as a source of secondary income, and more than half (55\%) of the properties has this activity as the main source, followed by livestock production (25\%). Most farmers have experience in the business because they have been raising horses for over 30 years and have higher school education.

Mostly, reproduction is done in three ways: natural breeding, artificial insemination and embryo transfer. This characteristic indicates that a great part of the properties uses advanced technology to ensure greatest reproductive success. The vaccines that are applied with more frequency are against rabies (94.9\%), influenza (43.6\%) and strangles (20\%). Moreover, $77.5 \%$ participate in events such as exhibitions and equestrian competitions (Table 1).

Regarding veterinary assitance, $87.5 \%$ reported having a person responsible for animals. Around 50\% frequently receive veterinarian care; $27.8 \%$ only when necessary and $22.2 \%$ only at the time of reproduction season. It was observed that most veterinarians were solely responsible for clinical and reproductive occurrences, which left a deficit in the pasture condition and might have reflected on the health of the animals and on the control of helminths.

The properties presented an average size of 116 hectares (ranging from 6 to 1500 ha) with a median of 60 animals. In most properties the animals were kept in five batches (from 4 to 8). Creators presented a median time of 30 years in equine production activity and a median of four workers per farm (Table 2).

There were no major differences between the properties in respect of management activities (Table 3). The most used diet was an association of mineral salt, grass and ration (37.5\%).

The vast majority of them do the grassland cleaning $(97.1 \%)$ once a year $(72.7 \%)$. The stool removal from the bays is done by $92.5 \%$ and only $12.5 \%$ remove them from the pickets, with $68.8 \%$ of them destined to the pasture. More than half use dunghills and 65\% perform the rotation of pasture; however, there is a consortium of pasture with other animals, mainly cattle. The exchange of the stalls beds is oftenly performed (75\%).

Removal of faeces from pickets and stalls prevents infection of treated animals and autoinfection. These are simple measures that help, in a considerable way, in the success of helminth control. Several studies have shown that pasture management is one of the tools to maximize the control of helminths in the property, thereby reducing the frequency of anthelmintic treatments in animals (Earle et al. 2002, O’Meara \& Mulcahy 2002).

Martins et al. (2009) found similar results to those of the present study, showing that $67.9 \%$ of creators perform pasture rotation, $89.3 \%$ remove faeces from stalls and, on the other hand, no creator removes feces from pickets, probably due to to labor and possible high costs. O 'Meara \& Mulcahy (2002) also reported that $71 \%$ of creators apply pasture rotation on their property and only 32\% withdraw feces from pickets. According to Molento et al. (2008) the removal of faeces twice a week in the rainy season and once during the drought is an efficient technique in the control of helminths in the pasture. These strategies, when used, help in the control of helminths and are effective in reducing grass contamination.

The farmers perception on helminths and on their control were also similar between the farms studied (Table 4).

The type of parasitism considered as the most important by creators was infestation by ticks, corroborating a study developed in Rio de Janeiro that pointed out the fact that unlike helminths, ticks are more visible in animals (Martins et al. 2009).

Regarding the time of higher occurrence of helminths, most creators claimed it to be during the rainy season, which is correct because heat and humidity provide ideal conditions for proliferation and survival of these parasites. Martins et al. (2009) in Rio de Janeiro identified a lack of knowledge about the topic, considering that this demonstrated the low importance given to helminths. All farmers allegedly control helminths, but only $17.5 \%$ perform stool tests. The ones who do, justify it on some brand of vermifuge offering their products and not for the sake of knowing the level of infection of the animals. The lack of theoretical/practical knowledge about the importance of preemergence fecal examination leads the creator to perform unnecessary treatments. Also in Ireland, $41 \%$ of the interviewed creators do not undergo fecal examination and $31 \%$ do so when they perceive a parasitic problem in animals (O'Meara \& Mulcahy 2002).

The most used vermifugation interval is every six months, with $97.5 \%$ treating all animals and, for $80 \%$, this activity is based on a determined period (Table 4). In Brazil, it was reported that $67.9 \%$ of the creators treated the animals in a range that could vary from 3 to 4 months, in which $89.3 \%$ based the treatment on a determined time and $82.1 \%$ did not use the rotation of anti-helmintics (Martins et al. 2009). In Ireland has been shown that $38 \%$ of creators apply the vermifuge within a range of 4-6 weeks and 58\% adopt a rapid anti-helminth rotation program (O'Meara \& Mulcahy 2002).

In $60 \%$ of the properties the creator is the one who carries out vermifugation, in which half of them claim to use the dose recommended by the package leaflet. However, only $20 \%$ use the weighing tape as a method of measuring the individual dose, $30 \%$ administer the same dose for adults and the same dose for foals (up to 2 years) and $47.5 \%$ estimate the weight of the animal. Some studies show similar results. In a study conducted in the central Paraíba region/RJ, 25\% of the creators performed the individual weighing for the calculation of the dose and $67.9 \%$ administered the same dose for adults and the same for foals (Martins et al. 2009). In Denmark and Ireland, studies show that most creators estimate the weight for the calculation of the dose per animal (Lendal et al. 1998, O’Meara \& Mulcahy 2002).

The emergence of resistance in a parasitic helminth population is directly related to the intensity and frequency of anthelmintic treatment of an exposed population ( $O^{\prime}$ Meara \& Mulcahy 2002). According to these authors, the practice of administering the anthelmintic treatment in all animals and not delineating an anthelmintic rotation program helps to accelerate the development of parasite resistance, a reality found in the properties of this study.

Another point to consider is the maintenance of the refuge population, which may aid in the dilution of resistance 
genes in parasite populations. The preservation of the refuge population, while controlling the population, requires routine EPG screening to be taken in order to identify the animals that actually need treatment. This strategy is different from the one normally used in the properties (which involves treating all animals without prior realization of EPG) and would help to reduce unnecessary treatments (Kaplan et al. 2004).

For the vermifuge choice, the main criteria adopted were to follow the veterinarian recommendations (37.5\%); to take into account the price of the product (17.5\%); and to use the product of the creator's choice (16\%). Martins et al. (2009) reported that the responsibility for the choice of vermifuge is the owner's (57.1\%) and Lendal et al. (1998) point out that $12 \%$ of the studied properties choose the dewormer according to its price.

The most frequently used anthelmintic on properties is ivermectin, which appears to be a common practice in several regions (Lendal et al. 1998, Earle et al. 2002, Martins et al. 2009). After treatment, farmers point out the existence of pelage improvement and observe worms in the feces.

It can be observed (Table 5) that the creators are used to acquire animals (65\%), and $57.7 \%$ buy animals more than once a year. The vast majority ( $80 \%$ ) reports that they always know the origin of the animal and the form of purchase varies between auction and informal purchase. More than half of the creators put the newly acquired animals in their properties without making any prior examination. The use of quarantine was recorded in $38.5 \%$ of the properties. This strategy is simple and can prevent the exchange of species of parasites/new diseases and/or resistant from the new animals to the ones already housed. However, the interview did not include the period used for implementing this strategy.

The age of horses ranged between six months and twenty-three years. There were 449 females (74.6\%) and 153 males (25.4\%), totaling 602 studied horses. All properties presented infected animals and EPG varied from zero to 11550 .

Amongst the 602 animals studied, 561 (93.2\%) were infected by some kind of helminth. The distribution of species or genera and the prevalence (\%) per animal per property are shown in Table 6. The most prevalent were the cyathostome and Oxyuris equi. The results of this study disagree in part with Umar et al. (2013) findings in Nigeria, in which the following order was found: Strongylus spp. (68.8\%), 0. equi $(27.1 \%)$, Strongyloides spp. (25\%), Parascaris equorum (6.3\%). Sharma et al. (2011), in India, found the following order: Cyathostome sp.
(62.22\%), Strongylus vulgaris (11.11\%), P. equorum $(6.03 \%)$, Trichostrongylus spp. (4.44\%), Oxyuris equi $(2.47 \%)$, S. edentatus (2.22\%). These differences can be attributed to climate differences, races, diagnostic techniques, sample size and forms of creation.

In Brazil, Canever et al. (2013) identified a higher prevalence of cyathostome and Martins et al. (2009), in Rio de Janeiro, identified the prevalence of animals and property, and some helminth presented prevalence similar to the present study findings. In the properties, the authors found the following prevalence: Cyathostome spp. (89.8\%), P. equorum (57.1\%), O. equi (50\%), Trichostrongylus axei (14.3\%), S. vulgaris (10.7\%), Gyalocephalus (G.) capitatus (7.1\%), S. edentatus (7.1\%). The prevalence of the 340 animals studied was: Strongyloidea (94.6\%), O. equi (14.1\%), P. equorum $(7.9 \%)$.

The occurrence of Oxyuris spp. is generally related to the breeding system (bays or pastures) and to the hygiene performed at the premises (barn, fence posts, fences, solid objects) of the property (Urquhart et al. 1996). In the present study, of the properties where this helminth was identified, $89.5 \%$ kept their animals in pickets and stalls. Another factor that may have influenced the results was the diagnostic method. It is known that in the fecal examination, only $5 \%$ of the samples are positive, since the females deposit the eggs around the anus.

It was observed that of the seven horses infected by Parascaris spp., 54.5\% were young from 6 to 24 months, $27 \%$ were newly-born females. According to Hinney et et al. (2011), the true prevalence of this parasite is age dependent.

The two equines infected with Trichostrongylus spp. belong to properties where it was observed and reported in the questionnaire the contact and consortium of pasture with cattle, a fact that reinforces the findings. Studies indicate that both the horse as cattle host this helminth (Smith et al. 1994).

Strongyles, S. edentatus and $S$. vulgaris were found in animals that were treated monthly, bi-monthly and six-monthly for $S$. vulgaris, and bi-monthly, in every four months and in every six months for $S$. edentatus. The animals infected with $S$. edentatus and $S$. vulgaris, according to information collected in the questionnaire, had been treated in a range of seven to 210 days and of 60 to 158 days, respectively. It is known that the pre treatment period for $S$. vulgaris and $S$. edentatus is 84 and 144 days, respectively (Bowman 2010). Therefore, it is clear that large strongyles resistance is present in the properties examined in this study.

Table 6. Prevalence of helminths in Mangalarga Marchador horse properties in southern Minas Gerais, 2012-2013

\begin{tabular}{|c|c|c|c|c|c|}
\hline \multirow{2}{*}{ Group } & \multirow{2}{*}{ Helminth } & \multicolumn{2}{|c|}{ Prevalence } & \multicolumn{2}{|c|}{ No. of equines } \\
\hline & & Property $(n=40)$ & Animals $(n=602)$ & + & - \\
\hline \multirow[t]{3}{*}{ Cyathostome } & Subfamily Cyathostominae & $100 \%$ & $96.40 \%$ & 534 & 20 \\
\hline & Poteriostomun spp. & $76.90 \%$ & $21.30 \%$ & 118 & 436 \\
\hline & Gyalocephalus capitatus & $74.40 \%$ & $15.70 \%$ & 87 & 467 \\
\hline \multirow[t]{3}{*}{ Large estrongyles } & Strongylus edentatus & $38.50 \%$ & $4.90 \%$ & 27 & 527 \\
\hline & Strongylus vulgaris & $17.90 \%$ & $1.80 \%$ & 10 & 544 \\
\hline & Triodontophorus spp. & $23.10 \%$ & $2.50 \%$ & 14 & 540 \\
\hline \multirow[t]{2}{*}{ Other helminths } & Oxyuris spp. & $59.00 \%$ & $8.00 \%$ & 48 & 554 \\
\hline & Parascaris spp. & $17.90 \%$ & $1.80 \%$ & 11 & 591 \\
\hline Trichostrongylus spp. & $5.10 \%$ & $0.40 \%$ & 2 & 552 & \\
\hline
\end{tabular}


In the first performed EPG (anthelmintic pretreatment), in $100 \%$ of the properties strongyle eggs were identified in feces, and $40.2 \%$ of the animals showed a high infection (>1000 epg) (Fig. 2).

Regarding properties with median pre-treatment EPG of animals, the median value was 775, ranging from 75 to $1450 \mathrm{EPG}$. It was observed that in $20.5 \%$ of the properties the animals were included at a level considered as a weak infection; $48.7 \%$ as a moderate level; and 30.8\% as a high level (Fig.3).

From these results, it can be observed that most of the animals showed moderate to massive infection, demonstrating the need for anthelmintic treatment for the elimination of parasites and also the rehabilitation of animal health.

In Brazil, Andrade et al. (2009) evaluated 50 traction horses, in Aracaju, Sergipe state and identified similar EPG test results to those of the present study: massive infection $(34.48 \%)$, moderate infection $(20.69 \%)$ and poor infection (44.83\%).

In France, Traversa et al. (2012), when studying 30 properties, identified in the pre EPG an average of 450 (median 300 epg, variation 50-3300 epg). In Nigeria with 48 horses, Umar et al. (2013) presented different results when compared to the present study: massive infection (4.8\%), moderate infection (34.3\%) and low infection (60.9\%). These results elucidate the high prevalence of helminths, pointing out that the occurrence of these parasites is widespread, being a risk to health and welfare of horses.

Productive, social and management factors were tested by t-test with the median EPG of the animals. Regarding the presence or absence of cattle in property, it was observed that the properties that raise cattle had an average median EPG larger than the others $(\mathrm{p}=0.024, \mathrm{x}=788.19)$. These and other associations are shown in Table 7.

In order to test the possible association with the prevalence of animals (\%) of the properties, the Mann-Whitthey and Kruskal-Wallis tests were performed for all independent variables.

High rates were found in both sampling times and it was verified that during dry season the median prevalence was significantly higher $(0,017)$. The median animal prevalence $(\%)$ per property median during dry season is $100\left(Q_{1}=94,4\right.$; $\mathrm{Q}_{3}=100$; $\min .=68.4 ; \max =100$ ) and during rainy season is $93,5\left(Q_{1}=80.8 ; Q_{3}=98.7 ; \min .=69.2 ; \max =100\right)$. This fact contradicts what farmers reported, since the rainy season favors the development of helminths, thus animal infection.

In Nigeria, Umar et al. (2013) found a significant difference $(\mathrm{p}<0.05)$ in the seasonal prevalence of helminths, $31.3 \%$ in the rainy period and $39.6 \%$ in the dry period.

The time of collection and the factors associated with farmers being primarily engaged in equine activities were factors that influenced the infection of animals (EPG) (Table 7). It was observed that during rainy season there is around six times more chances of finding massive infections in horses $(\mathrm{OR}=6,17 ; \mathrm{IC}=1.37-27.70 ; \mathrm{p}=0.023)$ and properties that prioritize equine activities showed less chance of high infestation $(\mathrm{OR}=0.14 ; \mathrm{IC}=0.03-0.66 ; \mathrm{p}=0.014)$. It is clear that the latter is not a direct association, but it is necessary to find the factors that determine this connection that might be linked mainly to greater care in the prevention and control activities. However, it was not tested in this study.

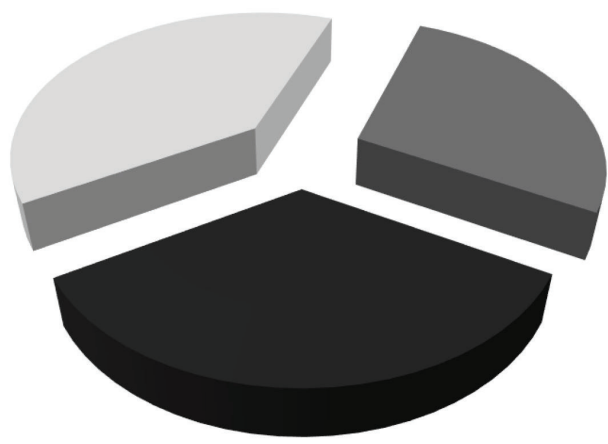

Low ( $\leq 450$ OPG) Moderate (500-1000 OPG) High (> 1000 OPG)

Fig.2. Infection classification of Mangalarga Marchador horse properties in southern Minas Gerais, 2012-2013, according to the value of the pre EPG.

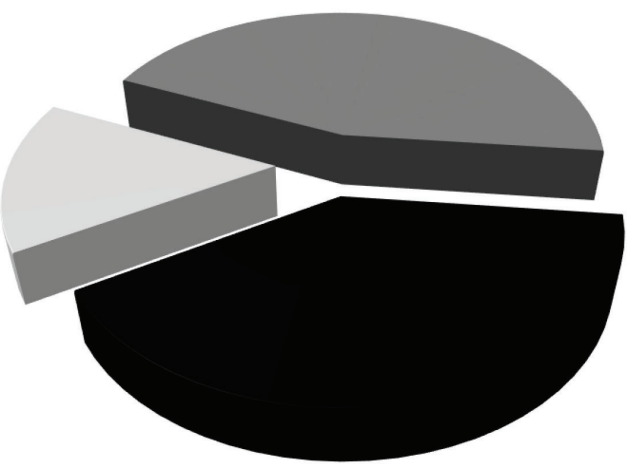

口Low ( $\leq 450$ OPG) 回Moderate (500-1000 OPG) High (> 1000 OPG)

Fig.3. Classification of the median pre EPG of equine in Mangalarga Marchador horse properties in southern Minas Gerais, 2012-2013, according to the level of infection.

Table 7. Factors related to median EPG of the horse properties in southern Minas Gerais, 2012-2013

\begin{tabular}{|c|c|c|c|c|c|c|}
\hline \multirow{2}{*}{ Factors $^{\mathrm{a}}$} & \multirow{2}{*}{ Categories } & \multicolumn{4}{|c|}{ Median de EPG/property } & \multirow{2}{*}{$\begin{array}{c}\mathrm{p} \\
\text { value }^{*}\end{array}$} \\
\hline & & $\mathrm{N}$ & Average & $\mathrm{Sd}$ & Min-max & \\
\hline \multirow{2}{*}{$\begin{array}{l}\text { Main equine } \\
\text { activity }\end{array}$} & Yes & 21 & 623.67 & 244.92 & $110.08-485.93$ & 0.003 \\
\hline & No & 15 & 921.67 & 291.92 & & \\
\hline \multirow[t]{2}{*}{ Cattle } & Yes & 32 & 788.19 & 309.57 & $-675.34--51.03$ & 0.024 \\
\hline & No & 4 & 425.00 & 287.63 & & \\
\hline \multirow[t]{2}{*}{ Grass } & Yes & 30 & 796.67 & 274.23 & $-558.10--27.94$ & 0.031 \\
\hline & No & 6 & 503.67 & 294.54 & & \\
\hline
\end{tabular}

a The productive, social and management factors raised in the interview were tested by the t-est but only those that showed statistical significance are shown in the table; $\mathrm{Sd}=$ standard deviation; ${ }^{*} \mathrm{p} \leq 0.05$.

\section{CONCLUSIONS}

The profile of Mangalarga Marchador Breeder Association (MM) farmers is characterized by high level of education, experience in equine activities, and the existence of other sources of income.

The farms have a fairly homogeneous creation profile.

The cyathostome were the most prevalent helminth, followed by Oxyuris and large strongyles. 
Most of the horses and the farms had moderate to massive infection, demonstrating that the control of helminths is being carried out improperly.

The farms which prioritize equine activities are less likely to have horses with massive infection.

The rainy season favored more massive infections than the prevalence of animals.

\section{REFERENCES}

Andrade T.L.F.S., Sobral J.C. \& Silva K.M.G. 2009. Avaliação clínica, hematológica e parasitária em equinos de tração na cidade de Aracaju, Sergipe. Acta Vet. Bras. 3:138-142.

Bevilaqua C.M.L., Rodrigues M.L. \& Concordet D. 1993. Ident: Strongylus vulgaris, S. equinus, S. edentatus, Triodontophorus spp., Poteriostomum spp., Gyalocephalus capitatus, Cylicocyclus radiatus, C. nassatus, C. minutus, C. poculatu. Revue Med. Vet. 44:989-995.

Bowman D. 2010. Parasitologia Veterinária de Georgis. Elsevier Brasil, Rio de Janeiro.

Canever R.J., Braga P.R.C., Boeckh A., Grycajuck M., Bier D. \& Molento M.B. 2013. Lack of Cyathostomin sp. reduction after anthelmintic treatment in horses in Brazil. Vet. Parasitol. 194(1):35-39. http://dx.doi.org/10.1016/j. vetpar.2012.12.020. PMid:23318166.

Earle C.G., Kington H.A. \& Coles G.C. 2002. Helminth control used by trainers of thoroughbreds in England. Vet. Rec. 150(13):405-408. http://dx.doi. org/10.1136/vr.150.13.405. PMid:11999277.

Frouco G.D.S. 2011. Estrongilidose em explorações equinas com vocação tauromáquica. Dissertação de Mestrado, Faculdade de Medicina Veterinária, Universidade Técnica de Lisboa, Lisboa. 79p.

Gordon H.M. \& Whitlock H.V. 1939. A new technique for counting nematode eggs in sheep faeces. J. Counc. Scient. Ind. Res. 12:50-52.

Hinney B., Wirtherle N.C., Kyule M., Miethe N., Zessin K.H. \& Clausen P.H. 2011. Prevalence of helminths in horses in the state of Brandenburg, Germany. Parasitol. Res. 108(5):1083-1091. http://dx.doi.org/10.1007/ s00436-011-2362-z. PMid:21472400.

Kaplan R.M., Klei T.R., Lyons E.T., Lester G., Courtney C.H., French D.D., Tolliver S.C., Vidyashankar A.N. \& Zhao Y. 2004. Prevalence of anthelmintic resistant cyathostomes on horse farms. J. Am. Vet. Med. Assoc. 225(6):903-910. http://dx.doi.org/10.2460/javma.2004.225.903. PMid:15485051.

Kornaś S., Gawor J., Cabaret J., Molenda K., Skalska M. \& Nowosad B. 2009. Morphometric identification of equid cyathostome (Nematoda: Cyathostominae) infective larvae. Vet. Parasitol. 162(3/4):290-294. http:// dx.doi.org/10.1016/j.vetpar.2009.03.018. PMid:19359100

Lendal S., Larsen M.M., Bjørn H., Craven J., Chriél M. \& Olsen S.N. 1998. A questionnaire survey on nematode control practices on horse farms in
Denmark and the existence of risk factors for the development of anthelmintic resistance. Vet. Parasitol. 78(1):49-63. http://dx.doi.org/10.1016/S03044017(98)00117-4. PMid:9703619.

Martins I.V.F., Verocai G.G., Correia T.R., Melo R.M.P.S., Pereira M.J.S., Scott F.B. \& Grisi L. 2009. Survey on control and management practices of equine helminthes infection. Pesq. Vet. Bras. 29(3):253-257. http://dx.doi. org/10.1590/S0100-736X2009000300011.

Molento M.B. 2005. Resistência parasitária em helmintos de equídeos e propostas de manejo. Ciência Rural 35(6):1469-1477. http://dx.doi. org/10.1590/S0103-84782005000600041.

Molento M.B., Antunes J., Bentes R.N. \& Coles G.C. 2008. Anthelmintic resistant nematodes in Brazilian horses. Vet. Rec. 162(12):384-385. http://dx.doi. org/10.1136/vr.162.12.384. PMid:18359933.

0'Meara B. \& Mulcahy G. 2002. A survey of helminth control practices in equine establishments in Czech Republic. Vet. Parasitol. 109(1-2):101-110. http://dx.doi.org/10.1016/S0304-4017(02)00249-2. PMid:12383629.

Rocha C., Leite R., Bruhn F., Guimarães A.M. \& Furlong J. 2011. Perceptions about the biology of Rhipicephalus (Boophilus) microplus among milk producers in Divinópolis, Minas Gerais. Revta Bras. Parasitol. Vet. 20(4):289-294. http://dx.doi.org/10.1590/S1984-29612011000400006. PMid:22166382.

Rocha C.M.B.M., Oliveira P.R., Leite R.C., Cardoso D.L., Calic S.B. \& Furlong J. 2006. Percepção dos produtores de leite do município de Passos, MG, sobre o carrapato Boophilus microplus (Acari: Ixodidae), 2001. Ciência Rural 36(4):1235-1242. http://dx.doi.org/10.1590/S0103-84782006000400029.

Silva M.G., Costa H.M. \& Silva A.V. 1994. Ocorrências de Trichostrongylus axei (Cobbold, 1879) em equídeos. Arq. Bras. Med. Vet. Zootec. 46:477-484.

Traversa D., Castagna G., Von Samson-Himmelstjerna G., Meloni S., Bartolini R., Geurden T., Pearce M.C., Woringer E., Besognet B., Milillo P. \& D’Espois M. 2012. Efficacy of major anthelmintics against horse cyathostomins in France. Vet. Parasitol. 188(3/4):294-300. http://dx.doi.org/10.1016/j. vetpar.2012.03.048. PMid:22538094.

Ueno H. \& Gonçalves P.C. 1998. Manual para Diagnóstico das Helmintoses de Ruminantes. Japan International Cooperation Agency, Tokyo, p.143.

Umar Y., Bawa M., Musa G. \& Mubarrak A. 2013. Prevalence of gastro-intestinal parasites in horses used for cadets training in Nigeria. J. Vet. Adv. 3(2):4348. http://dx.doi.org/10.5455/jva.20130219032443.

Urquhart G.M., Armour J., Duncan J.L., Dunn A.M. \& Jennings F.W. 1996. Parasitologia Veterinária. Guanabara Koogan, Rio de Janeiro, p.170.

Von Samson-Himmelstjerna G., Fritzen B., Demeler J., Schürmann S., Rohn K., Schnieder T. \& Epe C. 2007. Cases of reduced cyathostomin egg-reappearance period and failure of Parascaris equorum egg count reduction following ivermectin treatment as well as survey on pyrantel efficacy on German horse farms. Vet. Parasitol. 144(1/2):74-80. http://dx.doi.org/10.1016/j. vetpar.2006.09.036. PMid:17112667.Numus, consules iam porum opublisti, 